\title{
Electrophoretic behaviour of casein hydrolysis of modified atmosphere packaged Mozzarella cheese
}

\author{
Tanweer Alam ${ }^{1}$, Gyanendra Kumar Goyal ${ }^{2},{\text { Bimlesh } \text { Mann }^{3} \text {, Aastha Bhardwaj }}^{4}$ and Gaurav Kr Deshwal ${ }^{5}$
}

Received: 26 February 2019 / Accepted: 04 June 2019 / Published online: 28 October 2019

(c) Indian Dairy Association (India) 2019

\begin{abstract}
An attempt was undertaken to investigate the electrophoretic behaviour of Mozzarella cheese (MC) packed under modified atmospheric packaging (MAP) conditions in two different packaging materials (Cryovac (70 microns) (P1) and LLD/ BA*/Nylon-6/BA*/LDPE (110 microns) (P2). Adefinite quantity (approximately $250 \mathrm{~g}$ ) of MC was stored in high barrier bags under five varying conditions viz., air (C1), vacuum (C2), $100 \%$ $\mathrm{CO}_{2}(\mathrm{C} 3), 100 \% \mathrm{~N}_{2}(\mathrm{C} 4)$ and a mixture of $50 \% \mathrm{~N}_{2}$ and $50 \% \mathrm{CO}_{2}$ (C5) and stored at $7 \pm 1^{\circ} \mathrm{C}$. Periodically, the product was evaluated for its electrophoretic behaviour in the form of casein hydrolysis using low molecular weight (LMW) SDS-PAGE. During refrigeration storage, the degradation of protein started after four weeks with two major bands. However, there was no difference in the pattern of casein fractions of MAP Mozzarella cheese during storage at $7 \pm 1^{\circ} \mathrm{C}$ under 5 atmospheres upto 4 weeks, regardless of package type. After 8 weeks of storage, the intensity of bands decreased and lower molecular weight peptides increased.
\end{abstract}

Keywords: Electrophoretic properties, MAP, Mozzarella cheese, Refrigeration storage, Shelf-life,

${ }^{1}$ Indian Institute of Packaging, Delhi-110 092, India

2,3,5 National Dairy Research Institute, Karnal-132 001, Haryana, India ${ }^{4}$ Department of Food Technology, Jamia Hamdard, New Delhi-110 062, India

Tanweer Alam $(\bowtie)$

Indian Institute of Packaging

Delhi-110 092, India

Email: amtanweer@rediffmail.com;Phone: +919310601300
Modified Atmosphere Packaging (MAP) refers to the storage of any food product in high barrier packaging and flushing of gases inside the package which changes overtime due to activity of the product (Khoshgozaran et al. 2012). MAP possesses several advantages like shelf-life enhancement, quality preservation (Deshwal et al. 2018), quality degradation (Li et al. 2014), and reduced microbial activity (Alam and Goyal 2011). Mozzarella cheese (MC) is a 'pasta filata' type of cheese which refers to its stretching property. Under refrigeration storage without any MAP Mozzarella cheese possess a shelf life of only 15 days, as atmospheric air exaggerates the deteriorating reactions thus affecting sensory quality, texture and shelf-life adversely (Alam et al. 2016). Hydrolysis of cheese proteins is responsible for the development of texture and organoleptic features of most ripened varieties of cheese. The amount of intact casein had been found to affect even the stretching properties of Mozzarella cheese. Unlike most ripened varieties of cheese, protein hydrolysis profile of Mozzarella cheese are limited (Farkye et al. 1991). A very limited information is available on the influence of MAP on its electrophoretic properties during refrigeration. Therefore, a study was undertaken to investigate the influence of MAP on hydrolysis characteristics of Mozzarella cheese under refrigerated conditions.

The research work was carried out at National Dairy Research Institute (NDRI), India. A qualitative methodology was adopted for the evaluation of casein hydrolysis of modified atmosphere packaged Mozzarella cheese. Previously, Alam et al. (2016) prolonged the shelf-life of Mozzarella cheese by storing it under MAP and also studied variation in textural properties during storage. Another study on proteolysis of goat cheese (colourless and brined) was also carried out by Barac et al. (2013) using SDSPAGE (sodium dodecyl sulfate polyacrylamide gel electrophoresis) and a strong correlation between moisture content and proteolysis was reported.

For preparing Mozzarella cheese, mixture of buffalo (Murrah breed) and cow milk (crossbred cows) was procured from Experimental Dairy, NDRI, Karnal. The method described by Upadhyay, (2003) was used for preparing Mozzarella cheese with slight modifications. Two different high barrier packaging materials (Cryovac (70 microns) (P1) and LLD/BA*/Nylon-6/ 
Fig. 1 Electrophoretic behavior of casein hydrolysis of MAP Mozzarella cheese (Plate I: Fresh; Plate II: after four weeks: Plate III: after 12 weeks; IV: after 6 months: Plate $\mathrm{V}$ : after 12 months)

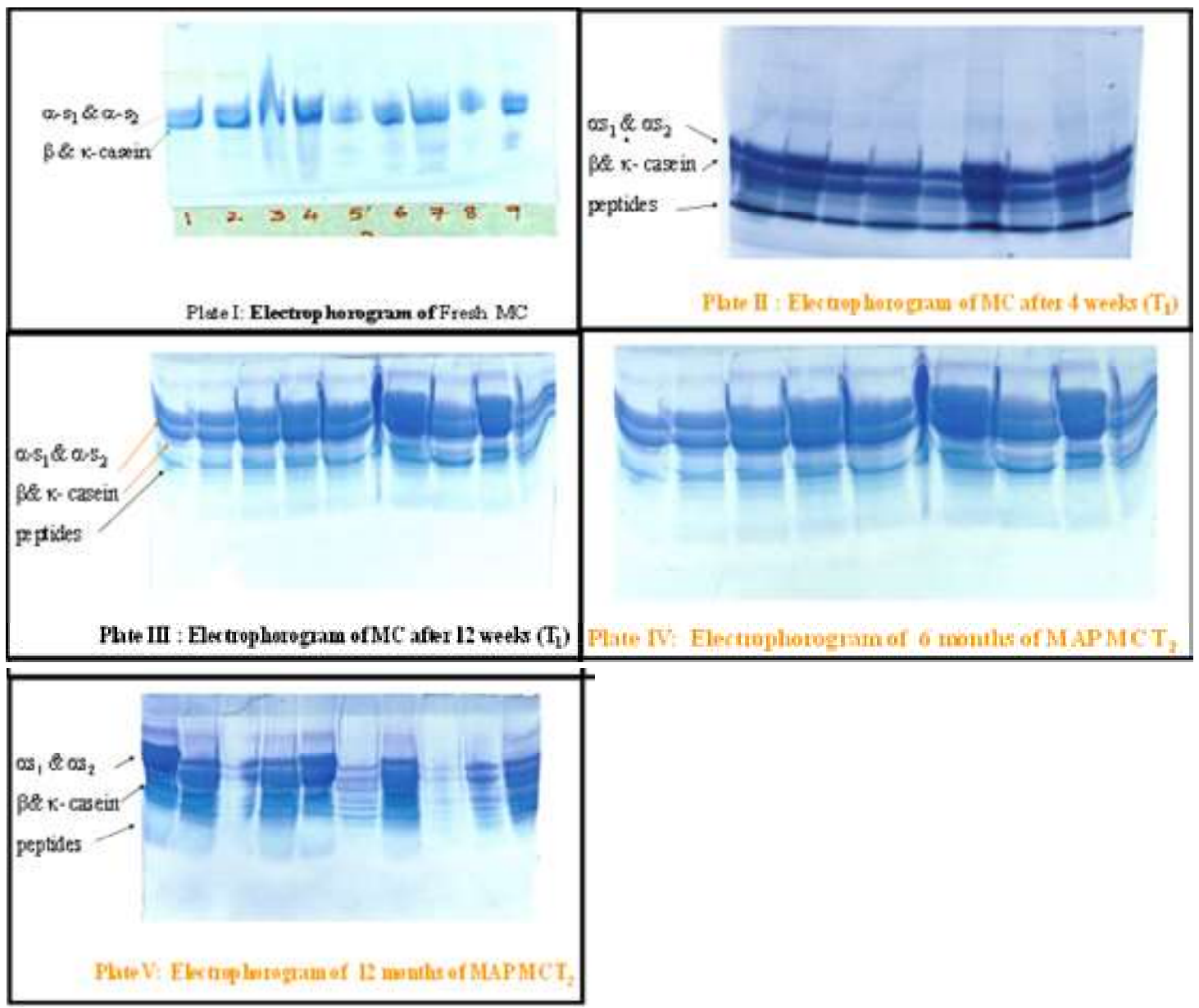

BA*/LDPE (110 microns) $(*$ with polymer additives) (P2) were used for the packaging of Mozzarella cheese samples. A definite quantity (approximately $250 \mathrm{~g}$ ) of $\mathrm{MC}$ was stored at $7 \pm 1^{\circ} \mathrm{C}$ in high barrier bags under five varying conditions viz., air $(\mathrm{C} 1)$, vacuum (C2), $100 \% \mathrm{CO}_{2}(\mathrm{C} 3), 100 \% \mathrm{~N}_{2}(\mathrm{C} 4)$ and a mixture of $50 \% \mathrm{~N}_{2}$ and $50 \% \mathrm{CO}_{2}(\mathrm{C} 5)$.

The hydrolysis of casein of Mozzarella cheese was determined using the technique described by Creamer (1991). The samples were electrophoresed using a mini gel electrophoresis unit (Techware, M/s Sigma Chemical, USA) based on low molecular weight (LMW) SDS-PAGE with power supply set at 210 volt (maximum) and $70 \mathrm{mAmphere} \mathrm{(maximum).} \mathrm{Approximately} 0.5$ grams of grated Mozzarella cheese samples were freeze dried in petriplates at $10 \mathrm{Mbar}\left(25^{\circ} \mathrm{C}\right)$. Freeze dried sample of Mozzarella cheese $(0.5 \mathrm{~g})$ was transferred to centrifuge tube containing 25 $\mathrm{ml}$ sample buffer. The tube was then centrifuged at $10,000 \mathrm{~g}$ for 10 minutes and $2 \mathrm{~mL}$ of the centre portion was taken, heated in a water bath at $100^{\circ} \mathrm{C}$ for 90 seconds and bromophenol blue solution was added. The resolving and stacking gel were prepared using acrylamide, bis- acrylamide, glycerol, Tris base, Tris $\mathrm{HCl}$ and SDS as per standard procedures. The gel solution was decanted into Mini-Slab apparatus and overlaid with about $0.5 \mathrm{ml}$ water. After the gel had set, the water was removed using tissue paper.
The stacking gel was mixed with $24 \mu 1$ of TEMED, adjusted to $20^{\circ} \mathrm{C}$, and $30 \mu \mathrm{l}$ of ammonium per sulphate solution was added. It was then poured into the former and the comb was inserted. After setting, excess gel and the comb were removed and $5 \mu 1$ of the $2 \%$ cheese solutions carefully loaded into each slot. The chamber buffer containing SDS, glycine and Tris base was then put into the apparatus. The gel was then stained with $50 \mathrm{ml}$ Coomassie brilliant blue $\mathrm{R}$ solution for one hour and destained for an hour, with $100 \mathrm{ml}$ change of destaining solution. Proper care was taken to prevent excess removal of too much dye at the very first change. The gel was then photographed. All the tests were performed twice with three runs $(n=2 \times 3)$ of each sample.

The proteolysis in cheese during storage was studied using electrophoresis. The degree of casein hydrolysis of stored and formation of smaller peptides in MAP Mozzarella cheese was examined using LMW SDS- PAGE. A perusal of Photoplate I (elctrophorogram prepared by using fresh Mozzarella cheese sample) revealed two bands for acid casein sample (lane 1) and two bands for fresh MC samples (lane 2). During refrigeration storage the degradation of protein started after four weeks with two major bands (Plate II) (Figure 1). However, there was no difference in the pattern of casein fractions of MAP MC during storage at $7 \pm 1{ }^{0} \mathrm{C}$ under 5 atmospheres $(\mathrm{C} 1, \mathrm{C} 2, \mathrm{C} 3, \mathrm{C} 4$ and $\mathrm{C} 5)$ 
upto 4 weeks. After 8 weeks of storage the intensity of bands decreased and lower molecular weight peptides increased. After three months of storage the intensity of bands and lower molecular weight peptides increased as shown in elctrophorogram (Plate III) (Figure 1). It is clear from the Photo plate III that degradation of $\beta$ - casein was not much, whereas $\alpha$ - casein degraded faster (C1) upto 6 weeks of storage. Similar results had been reported by various studies related to Mozzarella cheese (Farkye et al. 1991; Ghosh and Singh, 1996). Proportion of $\alpha_{\mathrm{S} 1}$ casein degradation to $\alpha_{\mathrm{S} 2}$ fraction was more prominent on 8 weeks in $\mathrm{C} 2$ and $\mathrm{C} 4$. This additional $\alpha_{\mathrm{s}}$ bands $\left(\alpha_{\mathrm{S} 1}\right.$ and $\left.\alpha_{\mathrm{S} 2}\right)$ would have appeared due to degradation of casein by microbial presence.

At deep freeze storage condition casein of $\mathrm{MC}$ samples did not degrade upto 6 months. The degradation of $\alpha_{S}$-casein started after 6 months (Photo plate IV) (Figure 1) and increased with the storage time till 12 months (Photo plate V) (Figure 1), regardless of package type and atmospheric conditions. The casein in deep frozen sample $\left(-10^{\circ} \mathrm{C}\right.$ to $\left.-15^{\circ} \mathrm{C}\right)$ didn't degrade upto 4 months of storage irrespective of the type of packaging material. The slight degradation in $\alpha_{\mathrm{s}}$-casein started after 6 months of storage and thereafter increased with the storage time.

These results pertaining to proteolysis of cheese samples during refrigeration storage $\left(7 \pm 1^{\circ} \mathrm{C}\right)$ also showed that the soluble $\mathrm{N}_{2}$ content was lowest in case of product that was packed under $\mathrm{C} 3$ followed by $\mathrm{C} 5, \mathrm{C} 4, \mathrm{C} 2$ and $\mathrm{C} 1$ respectively. An indirect proportional relationship between degree of proteolysis and hardness of cheese had been reported by Fedrick and Dulley (1984) and Fathollahi et al. (2010). Correspondingly, the decrease in hardness with storage time had been reported by Lawrence et al. (1987). However, Tunick et al. (1991) stated increase in hardness with decrease in moisture content of Mozzarella cheese ripened for varying storage period.

\section{Conclusions}

Electrophoretic plates reveal that there was no difference in the pattern of casein fractions of MAP Mozzarella cheese packages in all modified atmospheres upto 4 weeks irrespective of packaging during refrigeration storage. A lower degradation of $\beta$ - casein was observed, whereas $\alpha$ - casein degraded till 6 weeks of storage period (C1). Proportion of $\alpha_{\mathrm{S}}$-I casein degradation to $\alpha_{s}$ - II fraction was more prominent during $8^{\text {th }}$ week of storage in vacuum and $100 \% \mathrm{~N}_{2}$. At deep freeze storage condition casein of MC samples did not degrade upto 6 months.

\section{References}

Alam T, Goyal GK (2011) Effect of MAP on the microbiological quality of Mozzarella cheese stored in different packages at $7 \pm 10^{\circ} \mathrm{C}$. J Food Sci Technol 48: 120-123

Alam T, Saha NC, Bhardwaj A, Goyal GK (2016) Influence of Modified Atmosphere Packaging (MAP) on textural properties of Mozzarella cheese during refrigeration storage. Asian J Dairy Food Res 35:103110.

Barac MB, Smiljanic M, Pesic MB, Stanojevic SP, Jovanovic ST, Macej OD (2013) Primary proteolysis of white brined goat cheese monitored by high molarity Tris buffer SDS-PAGE system. Mljekarstvo Dairy 63: 122-131

Creamer LK (1991) Electrophoresis of cheese. Bullet Int Dairy Fed 261: 14-28

Deshwal GK, Panjagari NR, Badola R, Singh AK, Minz PS, Ganguly S, Alam T (2018) Characterization of biopolymer-based UV-activated intelligent oxygen indicator for food-packaging applications. J Packag Technol Res 2: 29-43

Farkye NY, Kiely LJ, Allshouse RD, Kindstedt PS (1991) Proteolysis in Mozzarella cheese during refrigerated storage. J Dairy Sci 74: 14331438

Fathollahi I, Hesari J, Azadmard S, Oustan S (2010) Influence of proteolysis and soluble calcium levels on textural changes in the interior and exterior of Iranian UF white cheese during ripening. World Acad Sci Eng Technol 66: 844-849

Fedrick IA, Dulley JR (1984) The effect of elevated storage temperatures on the rheology of Cheddar cheese. New Zealand J Dairy Sci Technol 19: $141-150$

Ghosh BC, Singh S (1996) Influence of starter culture on the quality of Mozzarella cheese from buffalo milk. Indian J Dairy Sci 49: 599606

Khoshgozaran S, Azizi MH, Fallah NB (2012) Evaluating the effect of modified atmosphere packaging on cheese characteristics: A review. Dairy Sci Technol 92: 1-24

Lawrence RC, Creamer LK, Gilles J (1987) Texture development during cheese ripening. J Dairy Sci 70: 1748-1760

Li Y, Ishikawa Y, Satake T, Kitazawa H, Qiu X, Rungchang S (2014) Effect of active modified atmosphere packaging with different initial gas compositions on nutritional compounds of shiitake mushrooms (Lentinus edodes). Postharvest Biol Technol 92: 107-113

Tunick MH, Makay KL, Smith PW, Holsinger VH (1991) Effects of composition and storage on the texture of Mozzarella cheese. Netherland Milk Dairy J 45: 117-125

Upadhyay, K. G. (2003). Essential of Cheese Making. Gujarat Agricultural University, Anand, 30-31 